\title{
HOMENAJE AL DR. JULIO C. TELLO
}

Las actuales investigaciones arqueológicas van respondiendo, cada vez con más acierto, las interrogantes que plantea el pasado de la cultura en el Área Andina. La formación científica que detentan quieres cultivan hoy las ciencias antropológicas y el grado de desarrollo de los métodos y técnicas de trabajo, particularmente los empleados en Arqueología, favorecen esos logros y, al mismo tiempo, relevan los esfuerzos de quienes se dedicaron en nuestro medio a tales disciplinas en años anteriores.

Los primeros años del presente siglo marcan el inicio de la introducción de métodos y procedimientos científicos en el quehacer arqueológico, y en ello tienen mucho que ver la labor del arqueólogo alemán Dr. Max Uhle y del peruano Dr. Julio C. Tello. A ellos debemos la institucionalización de la arqueología científica en nuestro país.

Julio C. Tello inició sus estudios en la ex Facultad de Medicina de nuestra Universidad y más adelante viajó al extranjero para estudiar Antropología en la Universidad de Harvard, graduándose de Master of Arts (1909) y Master of Anthropology (1911). Allí recibió lecciones de Franz Boas y Alex Hrdlicka, con quien más tarde exploraría los valles de la costa central. Desde entonces trabajó infatigablemente en busca de una explicación sobre los orígenes de la Cultura Andina. Tello deseaba completar el conocimiento de las secuencias culturales del antiguo Perú y fue así como descubrió la necrópolis de Paracas (1925), efectuó excavaciones en el valle de Santa (1926 y 1634), la quebrada de Chilca (1930), la Hoya del Marañón (1931), el valle de Empeña (1933), el Alto Marañón (1934 y 19379, Huanuco Viejo y Kotosh (1935), el valle del Urubamba (1942) y muchos otros sitios ya conocidos de Lima, Arequipa, Cuzco y Puno, llegando a identificar la importancia y la difusión de la cultura Chavín, cuyo principal centro ceremonial descubrió en 1919, dirigiendo la Primera Expedición Arqueológica al departamento de Ancash, enviada por la Universidad de San Marcos.

Precisamente, como consecuencia de dicha expedición científica, Tello obtiene las primeras informaciones sobre los "troncos" culturales Chavín y Huaylas que él expuso en su libro Introducción a la Historia Antigua del Perú, publicado en 1921. Más tarde, en 1934, con motivo de la Segunda Expedición, Tello formularía orgánicamente, por primera vez, lo que sería su tesis sobre el origen de la Civilización Peruana. 
Además de sus trabajos de investigación, Tello ejerció la dolencia universitaria y cumplió una labor de mucho mérito en los campos museológico y editorial. Nuestro Museo, fundado por él para estudiar los objetos recuperados en la ya mencionada expedición de 1919, es uno de los varios que Tello fundó y dirigió hasta su muerte. En el terreno de las publicaciones, además de las propias, que esperan ser presentadas orgánicamente en el futuro, Tello alentó y editó las revistas Inka (1923 y 1938), Wirakocha (1931) y Chaski (1940-1941).

Tello representa, pues, para la Arqueología Peruana, uno de sus más altos valores, por eso, el Museo de Arqueología y Etnología de la Universidad Nacional Mayor de San Marcos le rinde homenaje permanentemente.

Lima, Junio de 1972. 